\title{
ANTIMICROBIAL ACTIVITY AND HPLC ANALYSIS OF DAPHNE BLAGAYANA L. (THYMELAECEAE) EXTRACTS
}

KORESPONDENT

\section{AUTHORS}

Sovrlić M. ${ }^{1}$, Vasiljević $P{ }^{2}{ }^{2}$, Jušković $M .^{2}$, Mašković $P^{3}{ }^{3}$, Manojlović N. ${ }^{1}$

${ }^{1}$ Faculty of Medical Sciences, University of Kragujevac, Kragujevac, Serbia

${ }^{2}$ Faculty of Agriculture, University of Kragujevac, Čačak, Serbia

${ }^{3}$ Faculty of Science, University of Niš, Niš, Serbia

\author{
MIROSLAV SOVRLIĆ \\ Faculty of Medical Sciences, \\ University of Kragujevac, \\ Kragujevac, Serbia \\ $\square$ sofke-ph@hotmail.com
}

\section{SUMMARY}

The aim of this study was to investigate the antimicrobial activity and HPLC analysis of the methanol and chloroform extracts of leaves and twigs of endemic species Daphne blagayana collected from the area of Suva Mountain, Serbia. The antimicrobial activity, expressed as the values of MIC, were investigated on the 6 standardized bacterial strains and two strains of fungi. Amracin and ketoconazole are used as standard antibiotics. MIC values of the tested extracts were ranged from 15.62 to $125 \mu \mathrm{g} / \mathrm{ml}$. The strongest effect of the extracts exhibited against Klebsiella pneumoniae, Staphylococcus aureus and Proteus mirabilis. Results of the HPLC analysis showed the presence of a variety of secondary metabolites, one of which is 7,8-dihydroxycoumarin (daphnetin), which was identified in all the extracts tested. Daphnetin, as biologically active substance, is most responsible for the antimicrobial activity of the tested extracts, but its role can not exclude the influence of other secondary metabolites (phenols and flavonoids) present in the extracts, which may have a synergistic effect.

Keywords: Daphne blagayana, HPLC, dafnetin, antimicrobial activity.

\section{INTRODUCTION}

Daphne blagayana (traditional names: sling, oputnik, jeremicak) was first described by Slovenian botanist Henrik Freyer 1837 [1]. It belongs to the family Thymeleaceae. It is an evergreen perennial prostrate shrub, yellowish fragrant flowers, up to $30 \mathrm{~cm} \mathrm{[2].} \mathrm{It}$ occurs as Balkan endemic species with habitats in the western parts of Serbia, northern Montenegro, Bosnia and Herzegovina, and can be found in Slovenia, Romania, Bulgaria, Macedonia, Albania and Italy $[3,4,5]$. Plant species of the genus Daphne are widely used in folk medicine to treat various forms of cancer, skin diseases, rheumatism and toothache [6,7]. Various compounds isolated from these plants show antileucemic and antitumor activities $[8,9,10]$. Recent studies have also shown that isolated molecules from Daphne species exhibit antiinflammatory and antinociceptive effect by reducing the levels of cytokines that are directly involved in the inflammatory process, which indicates their effectiveness and use in the treatment of inflammatory diseases [11]. Previous studies have showed the presence of various secondary metabolites in Daphne species including lignans, lignins, flavonoids, coumarins and terpenoids $[12,13,14]$. Keeping in mind that secondary metabolites detected in these plant species possess pronounced biological activity, they are of a great importance for further investigation of the unexplored Daphne species. These species are a good source for the isolation of pure and natural substances that can potentially be used in the treatment of various diseases. The results of our previous studies have shown that the leaves and twigs of Daphne blagayana have a high content of phenols and flavonoids and potential antioxidant activity [15].

\section{STUDY OBJECTIVE}

The aim of this work was to investigate the antimicrobial activity of the chloroform and methanol extracts of twigs and leaves of the species Daphne blagayana and the identification of secondary metabolite daphnetin by HPLC method.

\section{MATHERIAL AND METHODS}

\section{Plant material}

The twigs and leaves of the plant Daphne blagayana were collected on Suva Planina in May 2011. Determination of the plant was carried out at the Department of Biology and Ecology, Faculty of Sciences, University of Nis, and the samples were deposited under number 5497.

\section{The strains of microorganisms}

Antimicrobial activity of the extracts of Daphne blagayana was investigated in 6 standard bacterial strains: Staphylococcus aureus ATCC 25923, ATCC 13883 Kleb- 
siella pneumoniae, Escherichia coli ATCC 25922, ATCC 13315 Proteus vulgaris, Proteus mirabilis ATCC 14153 and Bacillus subtilis ATCC 6633 and two strains of the fungus Candida albicans ATCC 10231 and Aspergillus niger ATCC 16404. The fungi cultivation was carried out on potatoglucose agar for 7 days at 20 OC under alternating light and dark conditions. After 7 days, recultivation of a new potato-glucose agar was carried out during the next 7 days. Bacteria were cultured on agar for 7 days at room temperature of $25^{\circ} \mathrm{C}$ under alternating light and dark conditions. The recultivation of bacterial strains was carried out on a new agar substrate for 5 days. The process of cultivation was performed four times until it obtained pure cultures. Identification of the test organisms was performed in the Department of Microbiology, Institute Torlak, Belgrade, Serbia.

\section{Preparation of plant extracts}

The air-dried leaves and twigs of Daphne blagayana $(60 \mathrm{~g})$ were crushed to a powder $(2-6 \mathrm{~mm})$, using a mill, and then separately extracted (4 hours) with the chloroform and methanol $(500 \mathrm{~mL})$ using Soxhlet apparatus. The liquid extracts are filtered through filter paper (Whatman, No. 1). Evaporation of the solvent used for the extraction was carried out under reduced pressure using a rotary evaporator. Dry extracts $(7.8 \mathrm{~g}$ chloroform and methanol $8.3 \mathrm{~g}$ ), which were used for further investigations, were kept in dark bottles.

\section{Microdilution method}

The minimum inhibitory concentration (MIC) of these extracts was determined by microdilution method using microtiter plates with 96 cavities [16]. The testing was carried out according to the bacteria in a Müller-Hinton broth as a medium, and as a medium for testing the activity of yeast used according to the Sabouraud dextrose broth. In the first row of the microtiter plate is pipetted, $100 \mu \mathrm{L}$ of solution extracts dissolved in methanol $(200 \mu \mathrm{L} / \mathrm{mL})$ and cirsimarin (dissolved in 10\% DMSO, 2 $\mathrm{mg} / \mathrm{mL}$ ). In the remaining wells plates was added $50 \mathrm{~mL}$ in Muller Hinton or Sabouraud-dextrose broth (supplemented with Tween 80 to a final concentration of $0.5 \%$ $(\mathrm{v} / \mathrm{v})$ for the analysis of extracts). A volume of $50 \mathrm{~mL}$ from the first row dents pipetted into the second row for each microtiter line, and then $50 \mathrm{~mL}$ of dilution scalar transferred from the second to twelfth rows of depressions. To each well is added per $10 \mathrm{~mL}$ of the indicator (resazurin solution was prepared by dissolving $270 \mathrm{mg}$ of a tablet in $40 \mathrm{~mL}$ of sterile distilled water) and $30 \mathrm{~mL}$ of a nutrient broth. Finally, each well was added $10 \mathrm{~mL}$ of the bacterial suspension $(106 \mathrm{CFU} / \mathrm{mL})$ or fungal spore suspension $(3 \times 104 \mathrm{CFU} / \mathrm{mL})$. The plates were then wrapped in foil to prevent dehydration and incubated for 24 hours at a temperature of 37 OC for bacteria and 48 hours at a temperature of $280 \mathrm{C}$ for 48 hours for fungi. All experiments were performed in three replicates. Changing colors in the recesses monitored visually. MIC values were determined using resazurin as an indicator. Resazurin is used as an oxidation-reduction indicator and it changes color to resorufin by reducing oxidoreductase within viable cells. Any change color from purple to pink or bleaching was recorded as a positive change. The lowest concentration at which color changes occurred was taken as the MIC value. MIC values shown are mean values of three measurements.

\section{Standard substance}

As a positive control for inhibiting the growth of bacteria was used amracin antibiotic, and as a control for testing the antifungal activity is used ketoconazole.

\section{High performance liquid chromatography (HPLC) analysis}

High performance liquid chromatography analysis (High Performance Liquid Chromatography) with UV detection was performed for the analysis of the compounds in the tested extracts. Analyses were performed on an Agilent 1200 Series appliance with a C18 column (C18; $25 \mathrm{~cm} 4.6 \mathrm{~mm}, 10 \mathrm{~m}$ ) and UV spectrophotometric detector [16]. The separations were carried out using a solvent system of acetonitrile-water-phosphoric acid (90:10:0.1, $\mathrm{v} / \mathrm{v} / \mathrm{v}$ ). Acetonitrile was HPLC grade and obtained from Merck (Darmstadt, Germany). Phosphoric acid is the reagent of analytical grade. Deionized water used in the experiment was obtained from Milli-Q® by the Water Purification System (Milford, MA, USA). The column is injected with $10 \mathrm{ml}$ of the sample solution at a flow rate $1.0 \mathrm{~mL} / \mathrm{min}$. Daphnetin (7,8-dihydroxycoumarin) was identified by comparison of retention time and the UV spectrum $(200-400 \mathrm{~nm})$ with the standard.

\section{Statistical analysis}

Student t-test was used for comparison the antimicrobial activity of $\mathrm{D}$. blagayana with the literature data of antimicrobial analysis of D. cneorum species [19].

\section{RESULTS}

\section{Antimicrobial activity}

The antibacterial activity of the methanol and chloroform extracts of the twigs and leaves of Daphne blagayana, expressed as minimum inhibitory concentration (MIC), was in the range of 15.62 to $125 \mu \mathrm{g} / \mathrm{mL}$ (Graphs 1 and 2). The lowest MIC value was observed in the case of the methanol extract of twigs and the chloroform extracts of leaves against $K$. pneumoniae, $S$. aureus and $P$. mirabilis $(15.62 \mu \mathrm{g} / \mathrm{mL})$. The lowest activity $(\mathrm{MIC}=125 \mu \mathrm{g} / \mathrm{mL})$ showed the chloroform extract of the twigs against $P$. vulgaris, the methanol extract of twigs against $B$. subtilis and the chloroform extract of leaves against $P$. vulgaris, as well as the methanol extract of leaves against $S$. aureus. In the case of antifungal activity of the methanol and chloroform extracts of twigs and leaves of Daphne blagayana, MIC values were ranged from 15.62 to $125 \mu \mathrm{g} / \mathrm{mL}$. The best activity was expressed by the methanol extract of twigs $(\mathrm{MIC}=15.62 \mu \mathrm{g} / \mathrm{mL})$ and the methanol extracts of leaves $(M I C=31.25 \mu \mathrm{g} / \mathrm{mL})$ against $A$. niger. The lowest activity $(\mathrm{MIC}=125 \mu \mathrm{g} / \mathrm{mL})$ was observed in the case of the methanol extract of twigs against $C$. albicans, the chloroform extract twigs against A. niger and the methanol extract of leaves against $C$. albicans. 
Chart 1. Antimicrobial activity (MIC; $\mu \mathrm{g} / \mathrm{mL})$ of the chloroform and methanol extract of twigs of $D$. blagayana

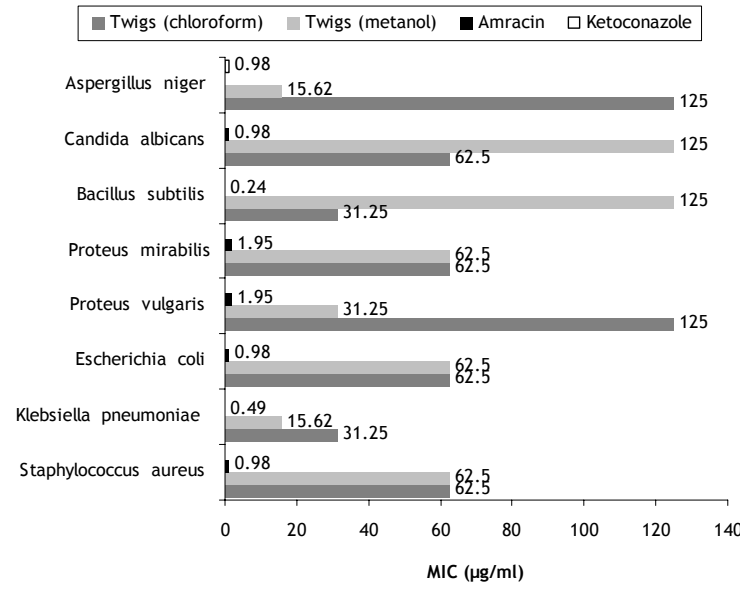

Chart 2. Antimicrobial activity (MIC; $\mu \mathrm{g} / \mathrm{mL}$ ) of the chloroform and methanol extract of leaves of $D$. blagayana

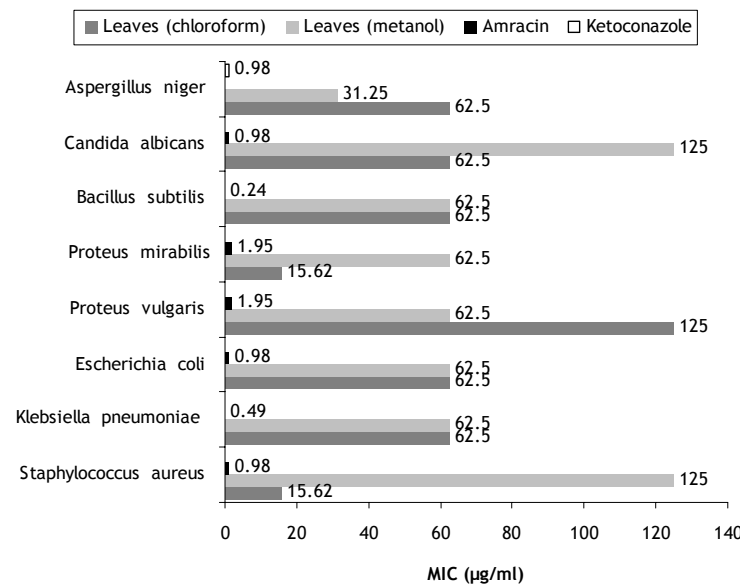

HPLC analysis of the extracts of Daphne blagayana

Figure 1. HPLC chromatogram of the chloroform extracts of twigs of Daphne blagayana

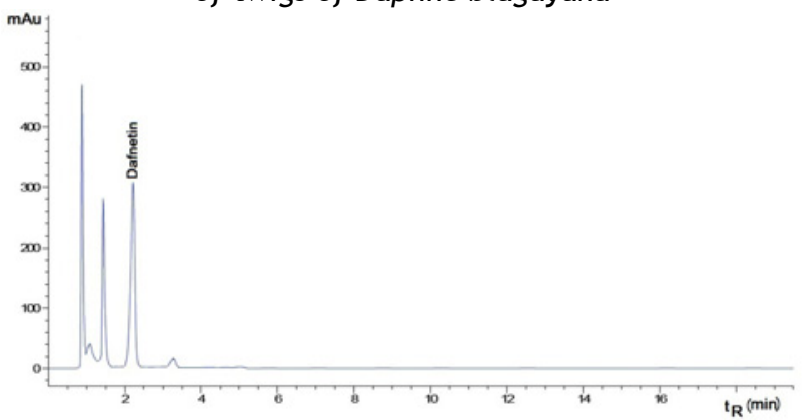

Figures 1-4 are shown the HPLC chromatograms of the methanol and chloroform extracts of leaves and twigs of the species Daphne blagayana. Results of the HPLC analysis of these extracts showed the presence of several different metabolites, among which there is also coumarine derivative daphnetin $(\mathrm{tR}=2.192)$. The identification of daphnetin was performed by compared the re- tention time and UV spectrum of standard daphnetin (Figure 5), with a retention times and UV spectra of constituents extracts. From the HPLC chromatograms of the tested extracts, it can be seen that for daphnetin occurring signals of greater intensity for the chloroform extract than the methanol extract. In addition, daphnetin in the extracts reveals the presence of other metabolites, which occur mainly at lower values of retention time. Analysis of their UV spectra can assume that these compounds belong to the group of coumarines and flavonoids.

Figure 2. HPLC chromatogram of the methanol extract of

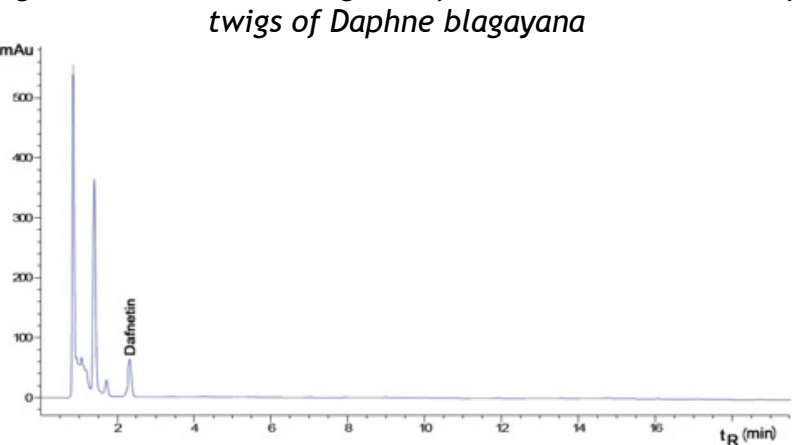

Figure 3. HPLC chromatogram of the chloroform extracts

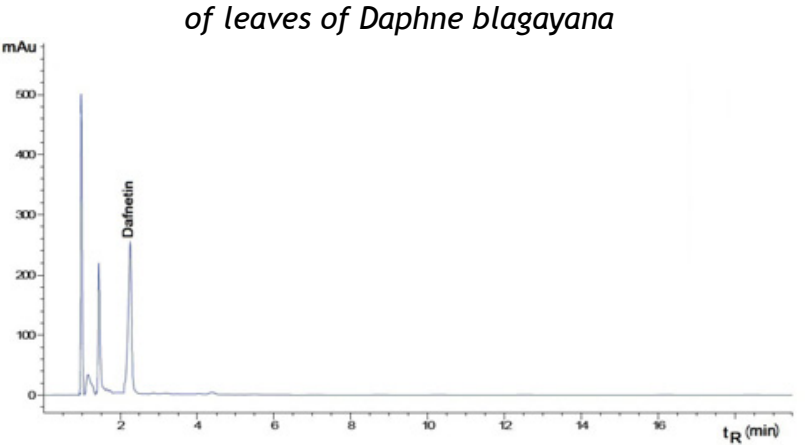

Figure 4. HPLC chromatogram of the methanol extract of

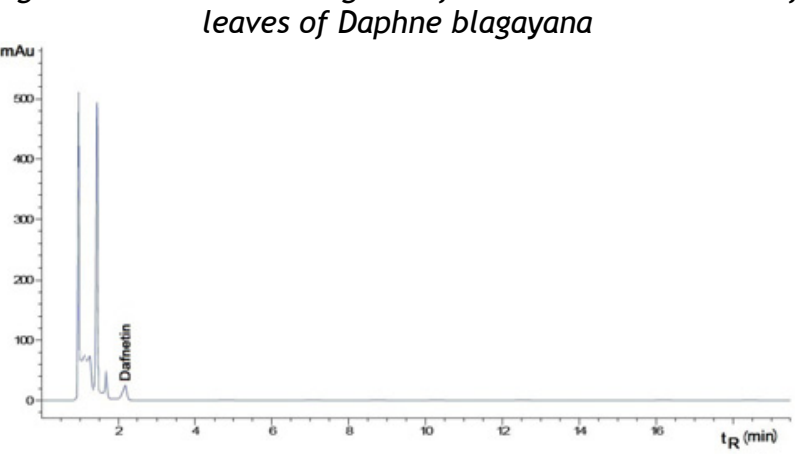

Figure 5. HPLC chromatogram and UV spectrum daph-

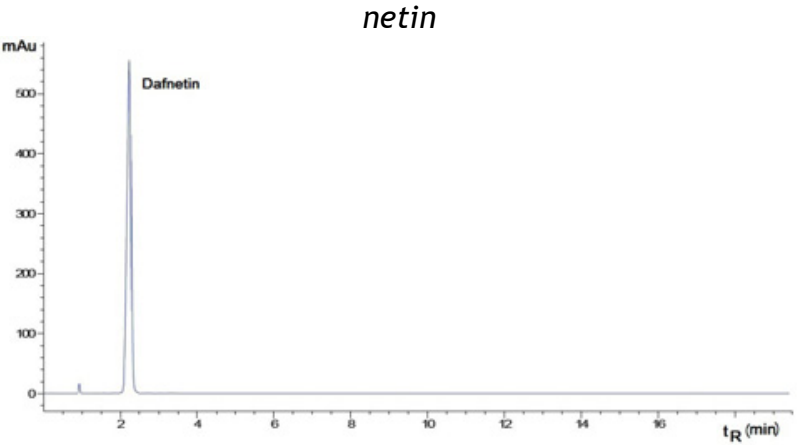


Table 1. Comparation of the antimicrobial activity species D. blagayana with previous research the species D. cneorum [19]

\begin{tabular}{|c|c|c|c|c|}
\hline \multirow{2}{*}{ Microorganisms } & \multicolumn{2}{|c|}{ Methanol extract of twigs } & \multicolumn{2}{|c|}{ Methanol extract of leaves } \\
\hline & D. blagayana & D. cneorum & D. blagayana & D. cneorum \\
\hline Staphylococcus aureus & 62.5 & 62.5 & 15.62 & 31.25 \\
\hline $\begin{array}{l}\text { Klebsiella pneumoniae } \\
\text { Escherichia coli }\end{array}$ & 31.25 & 31.25 & 62.5 & 31.25 \\
\hline Proteus vulgaris & 125 & 15.62 & 125 & 6.5 \\
\hline Proteus mirabilis & 62.5 & 62.5 & 15.62 & 6.5 \\
\hline Bacillus subtilis & 31.25 & 31.25 & 62.5 & 15.62 \\
\hline $\begin{array}{l}\text { Candida albicans } \\
\text { Aspergillus niger }\end{array}$ & 62.5 & $\frac{31.25}{62.5}$ & -62.5 & $\frac{15.62}{62.5}$ \\
\hline$p$ value $\leq 0.05$ & & & & \\
\hline
\end{tabular}

\section{DISCUSSION}

This paper presents the results of the antimicrobial activity and HPLC chromatograms of extracts of Daphne blagayana, collected at Suva Planina, May 2011. The paper is a continuation of the study on the biological activity of these plant species. In our previous work, the results of the total phenolic and flavonoid compositions and the methanol and chloroform extracts of twigs and leaves of this plant species, as well as examining their antioxidant activity have been presented [15]. The results showed that the tested extracts contained a high content of phenols and flavonoids, and to exhibit a good antioxidant activity, suggesting the potential use of this species in pharmacy and medicine. Guided by these results, our further research, whose results are presented in this paper, they are focused on testing the antimicrobial activity and phytochemical analysis of the extracts in a function of the presence of significant coumarin metabolite, daphnetin (7,8-dihydroxy coumarin). Knowing that previous studies have confirmed antimicrobial activity of daphnetin [17] it has shown its significant presence in Daphne species $[18,19,20]$, HPLC analysis was used to show its presence in the extracts. The identification of daphnetin in the tested extracts was performed by comparing its retention time and UV spectrum with retention times and UV spectra of metabolites present in the extracts. Absorption maxima of daphnetin occur at the following wavelengths: $204 \mathrm{~nm}$ (maximum with highest intensity), $267 \mathrm{~nm}$ (maximum with weakest intensity) and $325 \mathrm{~nm}$ (Figure 5). The antimicrobial activity of extracts depends not only on the presence daphetin, but also on the presence of other coumarin, phenolic and flavonoid metabolites, which have an impact on the activity. We assume that they may have a synergistic ef fect. Comparing the antimicrobial activity of the extracts obtained by our examination of the plant $D$. blagayana with the activity of other investigated Daphne species, it can be concluded that $D$. blagayana manifested specific activity in comparison to other species of Daphne. For example, the Student's t-test analysis showed the statistical significance in total antimicrobial potential of the methanol extract of D. blagayana in relation to the type D. cneorum while there is no statistical significance between the methanol extracts of twigs of these two species (Table 1).

Comparing with previous assay of the antimicrobial activity of the methanol extracts of species $D$. malyana [21], in which the MIC values ranged from 2.75 to $22.0 \mu \mathrm{g} / \mathrm{mL}$, it can be concluded that $\mathrm{D}$. blagayana having somewhat weaker antimicrobial activity.

\section{CONCLUSION}

Based on the obtained results, it can be concluded that the methanol and chloroform extracts of the species Daphne bagayana, exhibited specific antibacterial and antifungal activities against the tested microorganisms, whose values ranged from 15.62 to $125 \mu \mathrm{g} / \mathrm{mL}$. The tested extracts exhibited the strongest activity against following species: Klebsiella pneumoniae, Staphylococcus aureus and Proteus mirabilis. HPLC analysis confirmed the presence of the coumarin metabolite daphnetin in all the tested extracts in various quantities. Based on these and previous research, we can assume that the specific antimicrobial activity is likely to depend on the presence of this compound, and other constituents of these extracts. This plant can play a significant role as a source of the potential antimicrobial constituents.

\section{ACKNOWLEDGEMENTS}

This work was financially supported by the Junior Project (No. 2011/05) given by the Faculty of Medical sciences, University of Kragujevac, Serbia and Grant No. 172015 given by the Ministry of Education and Science of the Republic of Serbia.

\section{REFERENCES}

1. Paulin A.: Über die geographische Verbreitung von Daphne Blagayana Freyer. Von Alfons Paulin. Kleinmayr \& Bamberg. 1902: 3052.

2. Grey-Wilson C., Hawthorne L.: Gartenhandbuch. Steingartenpflanzen: Mit mehr als 450 Pflanzen. Royal Horticultural Society. 2005: 46. 
3. Martini F., Poldini L.: Daphne blagayana Freyer, a new species to the flora of Italy. Journal of Plant Taxonomy and Geography, 1990; 44: 295-306.

4. Dakskobler I., Vončina A., Gantar T.: Rastišča in združbene razmere vrste Daphne blagayana v povodju Idrijce. Hladnikia, 2011; 28: 3-16.

5. Yurukov S., Zhelev P.: The Woody Flora of Bulgaria: A Review. Schweizerische Zeitschrift fur Forstwesen, 2001; $152:$ 52-60.

6. Kupchan S.M., Baxter R.L.: Mezerein: antileukemic principle isolated from Daphne mezereum L. Science, 1975; 187: 652-653.

7. Kupchan S.M., Shizuri Y., Sumner W.C., Haynes HR., Leighton AP., Sickles BR.: Isolation and structural elucidation of new potent antileukemic diterpenoid esters from Gnidia species. J. Org. Chem., 1976; 41: 3850-3853.

8. Zhang W., Gao X., Gu X., Chen C.,Wei Z., Shi F.: Antitumour activity of daphnodorins from Daphne genkwa roots. International Immunopharmacology, 2007; 7: 128-134.

9. Chen J., Liu X., Si Y.P.: Determination of daphnetin in Daphne tangutica and its medicinal preparation by liquid chromatography. Analytica Chimica Acta, 2004; 523: 29-33.

10. Taniguchi M., Fujiwara A., Baba K., Wang NH.: Two biflavonoids from Daphne acutiloba. Phytochemistry, 1998; $49: 863-867$.

11. Kupeli E., Tosun A., Yesilada, E.: Assessment of anti-inflammatory and antinociceptive activities of Daphne pontica L. (Thymelaeaceae). Journal of Ethnopharmacology, 2007; 113: 332-337.

12. Cottigli F., Loy G., Garau D., Floris C., Caus M., Pompei R., Bonsignore L.: Antimicrobial evaluation of coumarins and flavonoids from the stems of Daphne gnidium. Phytomedicine, 2001; 8: 302-305.

13. Taninaka H., Takaishi Y., Honda G., Imakura Y., Sezik E., Yesilada E.: Terpenoids and aromatic compounds from Daphne oleoides ssp. oleoides. Phytochemistry, 1999; 52: 1525-1529.

14. Okunishi T., Umezawa T., Shimada M.: Isolation and enzymatic formation of lignans of Daphne genkwa and Daphne odora. Journal of wood science, 2001; 47: 383-388.

15. Manojlović N., Sovrlić M., Mašković P., Vasiljević P., Jušković M.: Phenolic and flavonoid content and antioxidant activity of Daphne blagayana groving in Serbia. Serbian Journal of Experimental and Clinical Research, 2014; 15: 21-27.

16. Satyajit D., Sarker LN., Kumarasamy Y.: Microtitre plate based antibacterial assay incorporateing resazurin as indicator of cell growth, and its application in the in vitro antibacterial screening of phytochemicals. Methods, 2007; 42: 321-324.

17. Cottigli, F., Loy, G., Garau, D., Floris, C., Caus, M., Pompei, R., Bonsignore, L.: (). Antimicrobial evaluation of coumarins and flavonoids from the stems of Daphne gnidium L. Phytomedicine, 2001; 8: 302-305.

18. Ueno, K., Saito, N.: Daphnetin, isolated from Daphne odora. Acta Crystallographica Section B: Structural Crystallography and Crystal Chemistry, 1976; 32: 946-948.

19. Manojlović, N., Mašković P., Vasiljević, P. Jelić, R., Jusković, M., Sovrlić, M., Mandić, L., Radojković, M.: HPLC analysis, antimicrobial and antioxidant activities of Daphne cneorum L. Hemijska industrija, 2012; 66: 709-716.

20. Chen, J., Liu, X., Shi, Y.: Determination of daphnetin in Daphne tangutica and its medicinal preparation by liquid chromatography. Analytica chimica acta, 2004; 523: 29-33.

21. Jusković, M., Vasiljević, P., Manojlović, N., Mihailov-Krstev, T., Stevanović, B.: (). Phytochemical and antimicrobial screening of leaves and stems of Balkan endemic species Daphne malyana Blečić. Biotechnology \& Biotechnological Equipment, 2012; 26: 3010-3015.

\section{SRPSKI}

\section{ANTIMIKROBNA AKTIVNOST I HPLC ANALIZA EKSTRAKATA BILJNE VRSTE DAPHNE BLAGAYANA L. (THYMELAECEAE)}

Sovrlić M. ${ }^{1}$, Vasiljević $P .^{2}$, Jušković $M .^{2}$, Mašković $P .^{3}$, Manojlović N. ${ }^{1}$

${ }_{1}^{1}$ Fakultet medicinskih nauka, Univerzitet u Kragujevcu, Srbija

${ }^{2}$ Agronomski fakultet, Univerzitet u Kragujevcu, Cačak, Srbija

${ }^{3}$ Prirodno-matematički fakultet, Univerzitet u Nišu, Sebija

\section{SAŽETAK}

Cilj ovog rada bio je ispitivanje antimikrobne aktivnosti i HPLC analiza matanolnih i hloroformskih ekstrakata listova i grančica endemske biljne vrste Daphne blagayana, prikupljene sa područja Suve planine u Srbiji. Antimikrobna aktivnost, izražena preko vrednosti MIC, ispitana je na 6 standardizovanih bakterijskih sojeva i dva soja gljivica. Amracin i ketokonazol su korišćeni kao standardni antibiotici. Dobijene MIC vrednosti su se kretale u opsegu od 15,62 do $125 \mu \mathrm{g} / \mathrm{mL}$, pri čemu su ekstrakti najjače dejstvo ispoljili prema vrstama, Klebsiella pneumoniae, Staphylococcus aureus i Proteus mirabilis. Rezultati HPLC analize pokazuju prisustvo više različitih sekundarnih metabolita, medju kojima je i 7,8-dihidroksi kumarin (dafnetin), koji je identifikovan u svim ispitivanim ekstraktima. Dafnetin, kao biološki aktivna supstanca, je velikim delom odgovoran za ispoljenu antimikrobnu aktivnost ekstrakata, ali se ne može isključiti ni uticaj ostalih sekundarnih metabolita (fenola, flavonoida) prisutnih u ispitivanim ekstraktima, koji mogu imati i sinergističko dejstvo.

Ključne reči: Daphne blagayana, HPLC, dafnetin, antimikrobna aktivnost 